\title{
Erratum to: Species-Specific Detection of Mycosphaerella polygoni-cuspidati as a Biological Control Agent for Fallopia japonica by PCR Assay
}

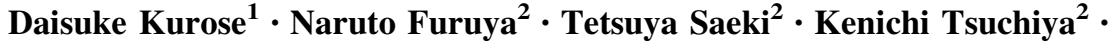 \\ Seiya Tsushima ${ }^{3} \cdot$ Marion K. Seier $^{1}$
}

Published online: 7 July 2017

(C) The Author(s) 2017

\section{Erratum to: Mol Biotechnol (2016) 58:626-633 DOI 10.1007/s12033-016-9962-x}

The article "Species-Specific Detection of Mycosphaerella polygoni-cuspidati as a Biological Control Agent for Fallopia japonica by PCR Assay", written by Daisuke Kurose, Naruto Furuya, Tetsuya Saeki, Kenichi Tsuchiya, Seiya Tsushima, and Marion K. Seier, was originally published Online First without open access. After publication in volume 58 , issue 10 , pages $626-633$, the author decided to opt for Open Choice and to make the article an open access publication. Therefore, the copyright of the article has been changed to (c) The Author(s) 2017, and the article is forthwith distributed under the terms of the Creative Commons Attribution 4.0 International License (http:// creativecommons.org/licenses/by/4.0/), which permits use, duplication, adaptation, distribution, and reproduction in any medium or format, as long as you give appropriate credit to the original author(s) and the source, provide a link to the Creative Commons License, and indicate if changes were made.

The online version of the original article can be found under doi:10.1007/s12033-016-9962-x.

Daisuke Kurose

D.Kurose@cabi.org

1 CABI Europe-UK, Bakeham Lane,

Egham, Surrey TW20 9TY, UK

2 Laboratory of Plant Pathology, Faculty of Agriculture, Kyushu University, 6-10-1 Hakozaki, Higashi-ku, Fukuoka 812-8581, Japan

3 Plant Pathology Laboratory, Faculty of Agriculture, Tokyo University of Agriculture, 1737 Funako, Atsugi,

Kanagawa 243-0034, Japan 